\title{
Radiological assessment of radionuclide contents in soils in Lower Silesian Voivodeship in the years 1988-2014
}

\author{
Aneta Łukaszek-Chmielewska ${ }^{1,{ }^{*}}$, Olga Stawarz $^{2}$, Krzysztof Isajenko $^{2}$, Barbara Piotrowska ${ }^{2}$, \\ and Martin Girard ${ }^{1}$ \\ ${ }^{1}$ Szkoła Główna Służby Pożarniczej, Faculty of Fire Safety Engineering, Department of Physics and \\ Chemistry, Warsaw, Poland \\ ${ }^{2}$ Centralne Laboratorium Ochrony Radiologicznej, Department of Dosimetry, Warsaw, Poland
}

\begin{abstract}
In 1986, the Chernobyl disaster provoked the uncontrolled release of significant amounts of radioactive substances, which caused surface contamination in Poland through radioactive isotopes. The most affected areas are Opole Voivodeship and part of Lower Silesian Voivoideship. Unfavorable meteorological conditions consisting of strong winds blowing from Chernobyl and local heavy rains favored the spread of a radioactive cloud, its shifting towards Poland and the accumulation of artificial isotopes in the soils of those regions [1]. Samples of the soils surface layers $(0-10 \mathrm{~cm})$ collected in different regions of Lower Silesian Voivodeship during the period 1988 - 2014 were studied. Changes in concentrations over time were analyzed for the following natural and artificial radionuclides: cesium $\left({ }^{137} \mathrm{Cs}\right.$ and $\left.{ }^{134} \mathrm{Cs}\right)$, potassium $\left({ }^{40} \mathrm{~K}\right)$, radium $\left({ }^{226} \mathrm{Ra}\right)$ and actinium $\left({ }^{228} \mathrm{Ac}\right)$. Since the disaster, the concentration of ${ }^{137} \mathrm{Cs}$ in the surface layer decreased continuously over time. The mean concentration of ${ }^{137} \mathrm{Cs}$ in the surface layer in Lower Silesian Voivodeship in 2014 was $1.46 \mathrm{kBq} / \mathrm{m}^{2}$, higher than the mean concentration for the whole Poland at $1.33 \mathrm{kBq} / \mathrm{m}^{2}$ [2]. Mean concentrations of other natural radionuclide such as ${ }^{226} \mathrm{Ra},{ }^{228} \mathrm{Ac}$ and ${ }^{40} \mathrm{~K}$ in the soils of Lower Silesian Voivodeship were also found to be higher than for the whole Poland [2].
\end{abstract}

\section{Introduction}

The natural environment has been contaminated by artificial isotopes as a result of nuclear explosions tests in the atmosphere in the sixties, and the failure of nuclear reactors such as: Chernobyl disaster (1986, former USSR), Windscale (1957, United Kingdom) and Fukushima (2011, Japan) or the explosion in the nuclear fuel reprocessing plant in Kyshtym (1979, former USSR). They caused the release of significant amounts of radioactive substances into the atmosphere, especially cesium $\left({ }^{134} \mathrm{Cs}\right.$ and $\left.{ }^{137} \mathrm{Cs}\right)$, strontium $\left({ }^{90} \mathrm{Sr}\right)$ and

\footnotetext{
* Corresponding author: alukaszek@sgsp.edu.pl
} 
iodine $\left({ }^{131} \mathrm{I}\right.$ and $\left.{ }^{133} \mathrm{I}\right)$ [3]. Radioactive isotopes from the air were deposited in the surface soils of the Earth through precipitations and are still present there due to their relatively long half-life. The results of scientific research have shown that the accumulation of cesium cations $\mathrm{Cs}^{+}$in a specific layer of the soil is impacted by its physiochemical properties, namely: the content of clay and organic matter, the $\mathrm{pH}$, the absorption properties, as well as the presence of other chemical compounds, which can form chemical bounds with the ions of radioactive metals. It was found, that the smaller the thickness of the organic layer, the higher the concentration of cesium isotopes $\left({ }^{137} \mathrm{Cs}\right)$ occurs in the surface layer $[4,5]$. That is also why approximately $99 \%$ of the cesium is found in the layer of the humus soils [4].

In Poland, the largest soil contamination occurred following the nuclear reactor disaster in Chernobyl in Ukrainian SSR on April 26, 1986. Just two days after the reactor's failure, the regional measuring station of the Radioactive Contamination Measurement Service in Mikołajki recorded an severalfold increase in the level of gamma radiation and a level of beta radiation around 700 higher than the average previous values. This was due to the unfavorable circulation of air masses during those days which caused the cloud from Chernobyl, which was first moving towards Belarus, to then divide in two, with one part of the cloud moving towards Scandinavia and the other part to the southwest. Then it was dispersed and arrived in Polish territory. Since the cloud was heavy and was declining due to gravity, it caused the strongest contamination in the region of today's Opole Voivodeship and part of Lower Silesian Voivodeship. At the same time, strong rains pouring in this region allowed the isotopes to settle in the surface soils [1]. To date, these voivodeships are characterized by an increased concentration of cesium isotope $\left({ }^{137} \mathrm{Cs}\right)$ in the soil.

The goal of this study was to determine the change in time of the surface concentrations of selected artificial and natural radionuclides. The artificial radionuclides studied are cesium isotopes ${ }^{134} \mathrm{Cs}$ and ${ }^{137} \mathrm{Cs}$, while the natural radionuclides studied are the following: radium isotope ${ }^{226} \mathrm{Ra}$, actinium isotope ${ }^{228} \mathrm{Ac}$ and potassium isotope ${ }^{40} \mathrm{~K}$ in soil samples from Lower Silesian Voivodeship.

\section{Methodology of measurements}

The spectrometric method (gamma ray spectrometry) was used to determine the concentration of radionuclides in the collected soil samples. The tests were performed using HPGe semiconductor detectors in cooperatioin with the Canberra GENIE 2000 system. The measurement time of each sample was 80000 seconds. The uncertainty of measuring the concentrations of individual radionuclides did not exceed $\pm 20 \%$. In order to calibrate the spectrometer, a reference source was used in the geometry of a Marinella vial with a volume of $0.5 \mathrm{dm}^{3}$ and a density of $1.3 \mathrm{~g} / \mathrm{cm}^{3}$ containing a mixture of the following radioactive elements: ${ }^{109} \mathrm{Cd},{ }^{57} \mathrm{Co},{ }^{139} \mathrm{Ce},{ }^{203} \mathrm{Hg},{ }^{113} \mathrm{Sn},{ }^{85} \mathrm{Sr},{ }^{137} \mathrm{Cs},{ }^{88} \mathrm{Y},{ }^{60} \mathrm{Co}$. To minimize the external radiation background, the detector was placed in a protective lead shielding [5]. For each soil sample, the surface concentration was determined for the following radionuclides: cesium $\left({ }^{134} \mathrm{Cs}\right.$ and $\left.{ }^{137} \mathrm{Cs}\right)$, as well as radium $\left({ }^{226} \mathrm{Ra}\right)$, actinium $\left({ }^{228} \mathrm{Ac}\right)$ and potassium $\left({ }^{40} \mathrm{~K}\right)$.

\subsection{Soil samples collection and preparation for radiometric analyzis}

Soil samples were collected from a depth of $0-10 \mathrm{~cm}$ from 26 measurement points situated in the following towns: Bogatynia, Bolesławów, Ceber, Chwałkowice, Długopole Zdrój, Dobrogoszcz, Duszniki Zdrój, Grabownica (Krośnice commune), Jakuszyce (since 1996), Jelcz - Laskowice (Laskowice Oławskie), Jelenia Góra, Karpacz, Kłodzko, Kudowa Zdrój, Lądek Zdrój, Legnica, Paprotki, Polkowice Dolne, Pszenno, Szczawno Zdrój, Szklarska Poręba, Swieradow Zdrój, Tarnów, Tomaszów Bolesławiecki, Wrocław (2 
samples - from a depth of $10 \mathrm{~cm}$ and $25 \mathrm{~cm}$ ) and Zgorzelec. Additionally, in the years 1988 - 1989, the soil was taken from the towns of Cieplice Śląskie and Płóczki Dolne; and in the years 1988 - 1992 from the towns of Krościna Mała, Kwietno, Ostroszowice, Polanica Zdrój and Zybiszów. Samples were taken from places where the micro-environment was not distorted by man through plowing or fertilization.

Each sample taken for the study was made of seven portions taken from six places lying on the perimeter of a circle with a radius of $1 \mathrm{~m}$, and the last portion was taken from the center of this circle. This was done to obtain a representative material for further research. The samples taken in this way were first dried at room temperature and then for 16 hours in an oven at $105^{\circ} \mathrm{C}$. Once dried, the samples were crushed and poured into measurement vials of a Marinella type $\left(\mathrm{V}_{\text {samples }}=0.45 \mathrm{dm}^{3}\right)$.

\section{Results}

The results of the concentration measurements for ${ }^{137} \mathrm{Cs}$ isotope in the surface layer of the soil taken in Lower Silesian Voivodeship for the years 1988-2014 are presented in Table 1. Additionally, the values of the mean concentration of those isotopes in the surface layer of the soil for Lower Silesian Voivodeship and Poland.

Table 1. Surface concentration of ${ }^{137} \mathrm{Cs}$ in soils taken from Lower Silesian Voivodeship in the years 1988-2014 and mean values for Lower Silesian Voivodeship and Poland ${ }^{1}$.

\begin{tabular}{|l|c|c|c|c|c|c|c|c|c|c|c|c|}
\hline \multirow{3}{*}{\multicolumn{1}{c|}{ Town }} & \multicolumn{10}{|c|}{ Surface concentration ${ }^{137} \mathbf{C s}\left[\mathbf{k B q} / \mathbf{m}^{2}\right]$} \\
\cline { 2 - 15 } & $\mathbf{1 9 8 8}$ & $\mathbf{1 9 8 9}$ & $\mathbf{1 9 9 2}$ & $\mathbf{1 9 9 6}$ & $\mathbf{1 9 9 8}$ & $\mathbf{2 0 0 0}$ & $\mathbf{2 0 0 4}$ & $\mathbf{2 0 0 6}$ & $\mathbf{2 0 0 8}$ & $\mathbf{2 0 1 0}$ & $\mathbf{2 0 1 2}$ & $\mathbf{2 0 1 4}$ \\
\hline Bogatynia & 2.03 & 2.70 & 2.04 & 0.83 & 1.34 & 1.19 & 1.20 & 1.30 & 1.19 & 1.48 & 0.89 & 1.10 \\
\hline Bolesławów & 22.00 & 30.50 & 27.40 & 17.90 & 22.70 & 20.30 & 10.60 & 20.20 & 17.10 & 18.20 & 10.20 & 7.72 \\
\hline Ceber & 1.62 & 1.54 & 0.92 & 1.47 & 1.01 & 0.91 & 1.14 & 1.01 & 0.77 & 0.61 & 0.69 & 0.52 \\
\hline Chwałkowice & 2.10 & 2.03 & 1.62 & 1.11 & 1.50 & 1.48 & 0.82 & 0.73 & 1.40 & 0.60 & 0.51 & 0.36 \\
\hline Cieplice Śląskie & 1.94 & 2.11 & - & - & - & - & - & - & - & - & - & - \\
\hline Długopole Zdrój & 47.32 & 46.40 & 49.93 & 30.16 & 34.16 & 30.80 & 16.81 & 19.56 & 19.63 & 23.78 & 17.97 & 4.63 \\
\hline Dobrogoszcz & 2.55 & 1.96 & 1.36 & 2.12 & 1.93 & 1.73 & 1.15 & 1.15 & 1.01 & 1.12 & 0.96 & 0.65 \\
\hline Duszniki Zdrój & 3.62 & 2.01 & 2.47 & 3.60 & 2.35 & 2.77 & 1.99 & 2.06 & 1.97 & 1.52 & 1.73 & 0.85 \\
\hline Grabownica & 2.46 & 1.72 & 1.61 & 2.78 & 1.55 & 1.59 & 0.87 & 0.80 & 0.80 & 0.83 & 0.57 & 0.45 \\
\hline Jakuszyce & - & - & - & 2.53 & 5.01 & 4.01 & 1.97 & 1.60 & 2.15 & 1.56 & 1.25 & 0.94 \\
\hline Jelcz - Laskowice & 2.54 & 0.98 & 2.61 & 2.02 & 1.97 & 1.54 & 1.14 & 1.23 & 1.61 & 1.26 & 0.95 & 0.50 \\
\hline Jelenia Góra & 2.00 & 2.09 & 2.34 & 1.57 & 2.87 & 2.78 & 1.43 & 1.83 & 1.65 & 2.33 & 1.16 & 1.04 \\
\hline Karpacz & 5.11 & 3.74 & 3.75 & 1.94 & 3.25 & 3.10 & 1.57 & 2.36 & 1.66 & 2.37 & 1.91 & 1.39 \\
\hline Kłodzko & 1.52 & 0.91 & 1.28 & 1.43 & 1.23 & 1.55 & 1.15 & 0.72 & 1.00 & 0.89 & 0.52 & 0.52 \\
\hline Krościna Mała & 1.73 & 1.79 & 1.39 & - & - & - & - & - & - & - & - & - \\
\hline Kudowa Zdrój & 4.99 & 2.20 & 3.45 & 3.69 & 2.53 & 3.20 & 2.72 & 3.34 & 2.34 & 2.00 & 1.45 & 0.31 \\
\hline Kwietno & 2.98 & 1.88 & 2.09 & - & - & - & - & - & - & - & - & - \\
\hline Lądek Zdrój & 25.70 & 32.4 & 33.10 & 20.3 & 17.30 & 29.30 & 15.10 & 19.00 & 17.60 & 12.10 & 12.00 & 8.62 \\
\hline
\end{tabular}




\begin{tabular}{|l|c|c|c|c|c|c|c|c|c|c|c|c|} 
Legnica & 1.05 & 0.87 & 1.05 & 0.47 & 0.53 & 0.56 & 0.53 & 0.51 & 0.70 & 0.56 & 0.44 & 0.38 \\
\hline Ostroszowice & 2.23 & 1.96 & 1.36 & - & - & - & - & - & - & - & - & - \\
\hline Paprotki & 2.88 & 2.61 & 2.69 & 1.21 & 2.45 & 2.30 & 1.62 & 1.25 & 1.47 & 1.05 & 1.14 & 0.87 \\
\hline Płóczki Dolne & 1.48 & 1.36 & - & - & - & - & - & - & - & - & - & - \\
\hline Polanica Zdrój & 4.81 & 3.30 & 3.93 & - & - & - & - & - & - & - & - & - \\
\hline Polkowice Dolne & 2.40 & 2.57 & 1.71 & 1.05 & 1.32 & 1.52 & 1.06 & 1.45 & 1.23 & 1.27 & 1.27 & 1.04 \\
\hline Pszenno & 3.00 & 2.01 & 1.88 & 1.13 & 2.01 & 1.94 & 1.64 & 0.97 & 1.02 & 0.95 & 0.63 & 0.34 \\
\hline Szczawno Zdrój & 2.16 & 2.20 & 4.00 & 0.74 & 1.30 & 1.50 & 0.81 & 0.96 & 0.83 & 1.20 & 0.80 & 0.47 \\
\hline Szklarska Poręba & 4.25 & 3.61 & 2.98 & 1.56 & 3.19 & 3.71 & 1.41 & 1.81 & 3.46 & 3.21 & 3.57 & 1.06 \\
\hline Świeradów Zdrój & 4.32 & 2.06 & 2.83 & 1.41 & 2.13 & 3.83 & 2.09 & 2.40 & 2.09 & 3.27 & 2.08 & 1.66 \\
\hline Tarnów & 2.64 & 1.86 & 1.85 & 2.75 & 2.47 & 1.93 & 1.17 & 1.08 & 1.23 & 1.24 & 1.21 & 0.76 \\
\hline Tomaszów B. & 2.25 & 1.47 & 1.28 & 0.67 & 1.24 & 1.03 & 0.90 & 0.65 & 1.05 & 1.29 & 0.68 & 0.82 \\
\hline Wrocław & 2.55 & 2.02 & 1.65 & 1.26 & 1.88 & 1.23 & 1.15 & 1.28 & 1.61 & 1.27 & 0.91 & 0.95 \\
\hline Zgorzelec & 0.97 & 1.95 & 1.74 & 0.91 & 1.01 & 1.34 & 0.98 & 0.86 & 1.04 & 0.85 & 0.81 & 0.05 \\
\hline Zybiszów & 3.63 & 2.56 & 2.56 & - & - & - & - & - & - & - & - & - \\
\hline $\begin{array}{l}\text { Lower Silesian } \\
\text { Voivodeship }\end{array}$ & $\mathbf{5 . 4 0}$ & $\mathbf{5 . 2 9}$ & $\mathbf{5 . 6 3}$ & $\mathbf{4 . 1 0}$ & $\mathbf{4 . 6 2}$ & $\mathbf{4 . 8 9}$ & $\mathbf{2 . 8 1}$ & $\mathbf{3 . 4 7}$ & $\mathbf{3 . 3 7}$ & $\mathbf{3 . 3 4}$ & $\mathbf{2 . 5 5}$ & $\mathbf{1 . 4 6}$ \\
\hline Poland & $\mathbf{4 . 6 4}$ & $\mathbf{4 . 6 8}$ & $\mathbf{4 . 2 4}$ & $\mathbf{3 . 6 5}$ & $\mathbf{3 . 4 9}$ & $\mathbf{3 . 2 0}$ & $\mathbf{2 . 5 4}$ & $\mathbf{2 . 4 1}$ & $\mathbf{2 . 1 0}$ & $\mathbf{1 . 9 3}$ & $\mathbf{1 . 5 3}$ & $\mathbf{1 . 3 3}$ \\
\hline
\end{tabular}

${ }^{1}$ All values of the surface concentration for ${ }^{137} \mathrm{Cs},{ }^{134} \mathrm{Cs},{ }^{226} \mathrm{Ra},{ }^{228} \mathrm{Ac}$ and ${ }^{40} \mathrm{~K}$ in the soils for Poland are measured by CLOR and published by the Radiological Polish Atlas and in the annual studies done at the request of the Main Inspectorate of the Environment al Protection.

It can be observed in Table 1, that the highest surface concentrations of ${ }^{137} \mathrm{Cs}$ in 2014 were recorded in Lądek Zdrój $\left(8.62 \mathrm{kBq} / \mathrm{m}^{2}\right)$, Bolesławów $\left(7.72 \mathrm{kBq} / \mathrm{m}^{2}\right)$ and Długopole Zdrój $\left(4.63 \mathrm{kBq} / \mathrm{m}^{2}\right)$, while the lowest concentration was recorded in Zgorzelec $(0.05$ $\mathrm{kBq} / \mathrm{m}^{2}$ ). At this time, the surface concentration value in Lądek Zdrój was $663 \%$ higher than the mean value for Polish soils During the years studied, the mean surface concentration of ${ }^{137} \mathrm{C}$ in Lower Silesian Voivodeship was between $1.46 \mathrm{kBq} / \mathrm{m}^{2}$ and 5.63 $\mathrm{kBq} / \mathrm{m}^{2}$, while it was between $1.33 \mathrm{kBq} / \mathrm{m}^{2}$ and $4.68 \mathrm{kBq} / \mathrm{m}^{2}$ for the whole Poland [2]. In 2014, the mean surface concentration was $1.33 \mathrm{kBq} / \mathrm{m}^{2}$ for Poland while a mean value of $1.46 \mathrm{kBq} / \mathrm{m}^{2}$ was observed in Lower Silesian Voivodeship, which means about $10 \%$ higher than for Poland. This is mainly due to the concentrations recorded in Lądek Zdrój, Bolesławów and Długopole Zdrój, which are the only ones being significantly higher than the mean value obtained for Poland. Considering the full time interval in which ${ }^{137} \mathrm{Cs}$ concentrations were recorded in the surface layer of soils in Lower Silesian Voivodeship, it can be noticed that their values systematically decrease. Nevertheless, the cesium ${ }^{137} \mathrm{C}$ is still present in the surface layers of soils, despite the fact that almost 30 years have passed since the failure of the nuclear reactor in Chernobyl. It is associated with its relatively long half-life of over 30.05 years $[2,5,6]$. In summary, there are still places (e.g. Lądek Zdrój and Bolesławów) in Lower Silesian Voivodeship where the surface concentration of cesium isotope ${ }^{137} \mathrm{C}$ in soils is several times higher than the mean value for Poland's soils, and therefore the area must be constantly monitored.

The next radioactive element, whose surface concentration was measured after the Chernobyl accident is another cesium isotope, ${ }^{134} \mathrm{Cs}$ with a half-life of 2.07 years $[2,5,6]$. Table 2 presents the measurements results of ${ }^{134} \mathrm{Cs}$ surface concentrations for soils collected in Lower Silesian Voivodeship during the years 1988-2000 and the mean values for Lower 
Silesian Voivodeship and for Poland. After $2000,{ }^{134} \mathrm{Cs}$ concentrations are below the lower limit of detection, which is why these results are no longer reported.

Table 2. Surface concentration of ${ }^{134} \mathrm{Cs}$ in soils taken from Lower Silesian Voivodeship in the years 1988-2014 and mean values for Lower Silesian Voivodeship and Poland.

\begin{tabular}{|c|c|c|c|c|c|c|c|}
\hline \multirow{2}{*}{ Town } & \multicolumn{3}{|c|}{$\begin{array}{l}\text { Surface concentration of } \\
{ }^{134} \mathrm{Cs}\left[\mathrm{kBq} / \mathrm{m}^{2}\right]\end{array}$} & \multirow{2}{*}{ Town } & \multicolumn{3}{|c|}{$\begin{array}{l}\text { Surface concentration of } \\
{ }_{134} \mathrm{Cs}\left[\mathrm{kBq} / \mathrm{m}^{2}\right]\end{array}$} \\
\hline & 1988 & 1996 & 2000 & & 1988 & 1996 & 2000 \\
\hline Bogatynia & 0.28 & $<$ LLD & $<$ LLD & Lądek Zdrój & 6.14 & 0.90 & 0.15 \\
\hline Bolesławów & 5.24 & 0.39 & 0.09 & Legnica & 0.19 & $<$ LLD & $<\operatorname{LLD}$ \\
\hline Ceber & $<$ LLD & $<$ LLD & $<$ LLD & Ostroszowice & 0.30 & - & - \\
\hline Chwałkowice & $<$ LLD & $<$ LLD & $<$ LLD & Paprotki & 0.28 & $<$ LLD & $<\mathrm{LLD}$ \\
\hline Cieplice Śląskie & 0.38 & - & - & Płóczki Dolne & 0.18 & - & - \\
\hline Długopole Zdrój & 10.70 & 1.32 & 0.17 & Polanica Zdrój & 0.44 & - & - \\
\hline Dobrogoszcz & 0.48 & $<$ LLD & $<$ LLD & $\begin{array}{l}\text { Polkowice } \\
\text { Dolne }\end{array}$ & $<$ LLD & $<$ LLD & $<\mathrm{LLD}$ \\
\hline Duszniki Zdrój & 0.31 & $<$ LLD & $<$ LLD & Pszenno & $<$ LLD & $<$ LLD & $<$ LLD \\
\hline Grabownica & 0.46 & $<$ LLD & $<$ LLD & $\begin{array}{l}\text { Szczawno } \\
\text { Zdrój }\end{array}$ & $<$ LLD & $<$ LLD & $<\mathrm{LLD}$ \\
\hline Jakuszyce & - & $<$ LLD & $<$ LLD & $\begin{array}{l}\text { Szklarska } \\
\text { Poręba }\end{array}$ & $<$ LLD & $<$ LLD & 0.05 \\
\hline Jelcz-Laskowice & 0.34 & $<$ LLD & $<$ LLD & $\begin{array}{l}\text { Świeradów } \\
\text { Zdrój }\end{array}$ & 0.32 & $<$ LLD & $<\mathrm{LLD}$ \\
\hline Jelenia Góra & $<$ LLD & $<$ LLD & $<$ LLD & Tarnów & $<$ LLD & 0.11 & $<$ LLD \\
\hline Karpacz & 0.93 & 0.06 & $<$ LLD & Tomaszów B. & $<$ LLD & $<$ LLD & $<$ LLD \\
\hline Kłodzko & $<$ LLD & $<$ LLD & $<$ LLD & Wrocław & 0.04 & $<$ LLD & $<$ LLD \\
\hline Krościna Mała & 0.24 & - & - & Zgorzelec & 0.27 & $<$ LLD & $<$ LLD \\
\hline Kudowa Zdrój & 0.25 & $<$ LLD & $<$ LLD & Zybiszów & 0.63 & - & - \\
\hline Kwietno & $<$ LLD & - & - & & & & \\
\hline $\begin{array}{c}\text { Lower Silesian } \\
\text { Voivodeship }\end{array}$ & 1.35 & 0.56 & 0.12 & Poland & 0.99 & 0.30 & 0.07 \\
\hline
\end{tabular}

LLD - Lower Limit Detection

The mean surface concentration of ${ }^{134} \mathrm{Cs}$ in the studied samples for the years 1988 2000 was within $0.12-1.35 \mathrm{kBq} / \mathrm{m}^{2}$, while the mean value for the whole of Poland was between $0.07 \mathrm{kBq} / \mathrm{m}^{2}$ and $0.99 \mathrm{kBq} / \mathrm{m}^{2}$ [2]. In 1988, two years after Chernobyl's accident the highest surface concentrations of ${ }^{134} \mathrm{Cs}$ were registered in Długopole Zdrój (10.70 $\left.\mathrm{kBq} / \mathrm{m}^{2}\right)$, Lądek Zdrój $\left(6.14 \mathrm{kBq} / \mathrm{m}^{2}\right)$ and Bolesławów $\left(5.24 \mathrm{kBq} / \mathrm{m}^{2}\right)$. For other towns the surface concentrations were registered in the limits $0.04-0.93 \mathrm{kBq} / \mathrm{m}^{2}$. In 2000 , the ${ }^{134} \mathrm{C}$ in Lower Silesian Voivodeship was present only in soils from the following towns: Bolesławów, Długopole Zdrój, Lądek Zdrój and Szklarska Poręba. The surface concentrations from other towns samples were below the lower limit of detection. This is due to the relatively short half-life period of the ${ }^{134} \mathrm{Cs}$ isotope. Comparing the mean surface concentrations of cesium isotopes in soils, i.e. ${ }^{134} \mathrm{Cs}$ and ${ }^{137} \mathrm{Cs}$, it can be observed that the mean values of ${ }^{137} \mathrm{Cs}$ concentrations are much higher than the mean concentrations of ${ }^{134} \mathrm{Cs}$ isotopes. In 1988, the ratio of these isotopes $\left({ }^{137} \mathrm{Cs} /{ }^{134} \mathrm{Cs}\right)$ was around 4 , and in 2000 it was 
almost 11. The mean surface concentrations of the two isotopes are higher in the Lower Silesian Voivodeship than for the whole of Poland.

In addition to the concentrations of artificial radionuclide, the concentrations of natural radionuclide were also measured in the surface soil samples studied. The measurements were done for radium $\left({ }^{226} \mathrm{Ra}\right)$, actinium $\left({ }^{228} \mathrm{Ac}\right)$ and potassium $\left({ }^{40} \mathrm{~K}\right)$ and are presented in Table 3 for radium, in Table 4 for actinium and in Table 5 for potassium ${ }^{40} \mathrm{~K}$.

Table 3. Surface concentration of ${ }^{226}$ Ra: mean values for Lower Silesian Voivodeship and Poland (1988 - 2014).

\begin{tabular}{|l|c|c|c|c|c|c|c|c|c|c|c|c|c|}
\hline \multirow{3}{*}{ Town } & \multicolumn{10}{|c|}{ Surface concentration ${ }^{226} \mathbf{R a}[\mathbf{B q} / \mathbf{k g}]$} \\
\cline { 2 - 14 } & $\mathbf{1 9 8 8}$ & $\mathbf{1 9 8 9}$ & $\mathbf{1 9 9 2}$ & $\mathbf{1 9 9 6}$ & $\mathbf{1 9 9 8}$ & $\mathbf{2 0 0 0}$ & $\mathbf{2 0 0 4}$ & $\mathbf{2 0 0 6}$ & $\mathbf{2 0 0 8}$ & $\mathbf{2 0 1 0}$ & $\mathbf{2 0 1 2}$ & $\mathbf{2 0 1 4}$ & Mean \\
\hline $\begin{array}{l}\text { Lower } \\
\text { Silesian } \\
\text { Voivodeship }\end{array}$ & 32.0 & 33.5 & 36.2 & 38.7 & 36.1 & 38.4 & 38.1 & 40.5 & 43.8 & 42.7 & 41.1 & 45.1 & 38.8 \\
\hline Poland & 24.7 & 25.8 & 24.6 & 25.3 & 24.1 & 24.0 & 25.0 & 25.8 & 25.8 & 25.3 & 24.8 & 31.9 & 25.6 \\
\hline
\end{tabular}

Table 4. Surface concentration of ${ }^{228}$ Ac: mean values for Lower Silesian Voivodeship and Poland (1988-2014).

\begin{tabular}{|l|c|c|c|c|c|c|c|c|c|c|c|c|c|}
\hline \multirow{3}{*}{ Town } & \multicolumn{10}{|c|}{ Surface concentration ${ }^{228} \mathbf{A c}[\mathbf{B q} / \mathbf{k g}]$} \\
\cline { 2 - 13 } & $\mathbf{1 9 8 8}$ & $\mathbf{1 9 8 9}$ & $\mathbf{1 9 9 2}$ & $\mathbf{1 9 9 6}$ & $\mathbf{1 9 9 8}$ & $\mathbf{2 0 0 0}$ & $\mathbf{2 0 0 4}$ & $\mathbf{2 0 0 6}$ & $\mathbf{2 0 0 8}$ & $\mathbf{2 0 1 0}$ & $\mathbf{2 0 1 2}$ & $\mathbf{2 0 1 4}$ & Mean \\
\hline $\begin{array}{l}\text { Lower } \\
\text { Silesian } \\
\text { Voivodeship }\end{array}$ & 25.8 & 24.8 & 26.9 & 29.0 & 30.0 & 33.9 & 32.3 & 33.3 & 37.5 & 36.9 & 36.0 & 32.8 & 31.6 \\
\hline Poland & 19.6 & 20.7 & 20.2 & 20.7 & 22.0 & 23.3 & 23.4 & 23.2 & 24.3 & 24.4 & 23.8 & 22.9 & 22.3 \\
\hline
\end{tabular}

Table 5. Surface concentration of ${ }^{40} \mathrm{~K}$ : mean values for Lower Silesian Voivodeship and Poland (1988-2014).

\begin{tabular}{|l|c|c|c|c|c|c|c|c|c|c|c|c|c|}
\hline \multirow{3}{*}{ Town } & \multicolumn{10}{|c|}{ Surface concentration ${ }^{40} \mathbf{K}[\mathbf{B q} / \mathbf{k g}]$} \\
\cline { 2 - 13 } & $\mathbf{1 9 8 8}$ & $\mathbf{1 9 8 9}$ & $\mathbf{1 9 9 2}$ & $\mathbf{1 9 9 6}$ & $\mathbf{1 9 9 8}$ & $\mathbf{2 0 0 0}$ & $\mathbf{2 0 0 4}$ & $\mathbf{2 0 0 6}$ & $\mathbf{2 0 0 8}$ & $\mathbf{2 0 1 0}$ & $\mathbf{2 0 1 2}$ & $\mathbf{2 0 1 4}$ & Mean \\
\hline $\begin{array}{l}\text { Lower } \\
\text { Silesian } \\
\text { Voivodeship }\end{array}$ & 498 & 455 & 516 & 552 & 536 & 525 & 542 & 526 & 584 & 577 & 551 & 542 & 522 \\
\hline Poland & 394 & 398 & 402 & 410 & 403 & 399 & 406 & 403 & 416 & 428 & 415 & 390 & 406 \\
\hline
\end{tabular}

The results of surface concentration of ${ }^{226} \mathrm{Ra}$, presented in Tables 3, show that during a period of 27 years, i.e. in the period from 1988 to 2014, the values of the surface concentration of radium ${ }^{226} \mathrm{Ra}$ remained at a similar level due to the very long half-life period of this isotope of about 1600 years $[2,5,6]$. The mean surface concentration of ${ }^{226} \mathrm{Ra}$ in soil samples taken from Lower Silesian Voivodeship was between $32.0 \mathrm{~Bq} / \mathrm{kg}$ and 45.1 $\mathrm{Bq} / \mathrm{kg}$ in the years $1988-2014$. In the same period of time, the mean surface concentration of this isotope in Poland was between $24.0 \mathrm{~Bq} / \mathrm{kg}$ and $31.9 \mathrm{~Bq} / \mathrm{kg}$, slightly less than for Lower Silesian Voivodeship. This is most likely caused by the geological structure of the studied region, Lower Silesian Voivodeship, where an increased concentration of uranium in the surface layer of soils is observed. The mean value of uranium concentration in soils for Poland is $1.1 \mathrm{ppm}$, while in the Karkonosze-Izera block its concentration exceeds 13 ppm $[5,6]$. 
The results of the surface concentration of ${ }^{228} \mathrm{Ac}$ are presented in Table 4 . The half-life of ${ }^{228} \mathrm{Ac}$ is equal to 6.13 hours, however, this radionuclide in soil is in a radioactive equilibrium with other longer living isotopes: radium ${ }^{228} \mathrm{Ra}\left(\mathrm{T}_{1 / 2}=5.75\right.$ years $)$ and thorium ${ }^{232} \mathrm{Th}\left(\mathrm{T}_{1 / 2}=1.4 \cdot 10^{10}\right.$ years $)[2,5-6] .{ }^{228} \mathrm{Ac}$ concentration values in soil samples remained at a similar level during the whole period of time analyzed. The recorded concentration of ${ }^{228} \mathrm{Ac}$ in the surface layer of soils for Poland is between $19.6 \mathrm{~Bq} / \mathrm{kg}$ and $24.4 \mathrm{~Bq} / \mathrm{kg}$. In Lower Silesian Voivodeship, the mean surface concentration of this isotope is between 24.8 $\mathrm{Bq} / \mathrm{kg}$ and $37.5 \mathrm{~Bq} / \mathrm{kg}$. The mean value of surface concentrations of actinium calculated for samples from the whole of Poland in the period of time between 1988 and 2014 is more than $29 \%$ lower than the mean concentration of this isotope occurred in the surface layer of soils in Lower Silesian Voivodeship. The main cause of these slightly enhanced levels of ${ }^{228} \mathrm{Ra}$ and ${ }^{232} \mathrm{Th}$ is the geological structure of this region and therefore soils from Lower Silesian Voivodeship show a higher concentration of this element than the rest of Poland [5, $6]$.

The last naturally occurring radionuclide in the environment studied is the potassium isotope ${ }^{40} \mathrm{~K}$ with a half-life period of $1,27 \cdot 10^{9}$ years $[2,5,6]$. The surface concentrations of this isotope during the period 1988 - 2014 are presented in Table 5 with the mean values for Lower Silesian Voivodeship and for Poland. The observed mean concentration of potassium in the case of Lower Silesian Voivodeship over the full period of time was between 455 $\mathrm{Bq} / \mathrm{kg}$ and $585 \mathrm{~Bq} / \mathrm{kg}$, while for the whole of Poland they are between $390 \mathrm{~Bq} / \mathrm{kg}$ and 428 $\mathrm{Bq} / \mathrm{kg}$. The main reason for increased concentration of potassium in the surface layer in Lower Silesian Voivodeship is the geological structure, and more precisely the main rock which is formed of granite and contains in its composition a relatively large amount of elemental potassium. In addition, high concentrations of this isotope are also seen in the regions covered by forests, i.e. in the north-eastern part of Poland $[5,6]$.

\section{Conclusion}

Based on the measurements made during the period of years 1988 - 2014, it can be concluded that the concentrations of both natural and artificial isotopes in the soil samples taken from the area of Lower Silesian Voivodship are elevated in relation to those obtained for the whole of Poland.

In the case of the ${ }^{137} \mathrm{Cs}$ cesium isotope, it can be noticed that over time, i.e. from 1988 to 2014, in the soils of Lower Silesian Voivodeship there has been a decrease of almost 4 times in its concentration. It is caused by its radioactive decay as well as its transfer into deeper layers of soil. The average surface concentration of cesium ${ }^{137} \mathrm{C}$ at all measurement points located in Lower Silesian Voivodship was in 2014 year about 10\% higher than the average concentration of this radionuclide obtained for Polish soils. However, the surface concentration of cesium ${ }^{134} \mathrm{Cs}$ in the soil at all measurement points located in the province of Lower Silesian since 2004 is below the its detection limit.

The average concentrations of natural radionuclide, i.e. radium ${ }^{226} \mathrm{Ra}$, actinium ${ }^{228} \mathrm{Ac}$, and ${ }^{40} \mathrm{~K}$ potassium in the soils of Lower Silesian Voivodship, are increased by about 1.3 1.5 in relation to the average concentrations obtained for soils of the whole of Poland. This is mainly due to the geological structure of the studied area and a small contribution can be made by human activity.

The main reason for the presence of cesium isotopes in soils was the failure of the nuclear reactor in Chernobyl and the strong contamination of Lower Silesian region. The slightly increased concentration of the cesium isotope ${ }^{137} \mathrm{Cs}$ above $1 \mathrm{kBq} / \mathrm{m}^{2}$ is still observed and therefore, further research of these isotope concentrations should be continued. 


\section{References}

1. K. Isajenko, B. Piotrowska, A. Stawarz, A. Łukaszek-Chmielewska, S. Krawczyńska, Bezpieczeństwo i Technika Pożarnicza, 46, 2, 42-54 (2017)

2. K. Isajenko, M. Kardaś, K. Wojtkowski, B. Piotrowska., I. Kwiatkowska, O. Stawarz, A. Ząbek, A. Kiełbasińska, Raport roczny dotyczący wykonania III etapu pracy: Monitoring Stężenia ${ }^{137}$ Cs w glebie w latach 2014-2015, CLOR, Warszawa (2016)

3. A. Łukaszek-Chmielewska, K. Isajenko, Przegląd Pożarniczy, 1, (2017)

4. S.Wołkowicz, R. Strzelecki, Przegląd Geologiczny 50, 10/2, 941-944 (2002)

5. K. Isajenko, A. Łukaszek-Chmielewska, M. Smolarkiewicz, T. Zwęgliński, Zeszyty Naukowe SGSP, 60, 4 (2016)

6. K. Isajenko, B. Piotrowska, M. Fujak, M. Kardaś, Atlas radiologiczny Polski 2011, Biblioteka Monitoringu Środowiska (2011) 